\title{
THE IJTIMA'I METHODOLOGICAL APPROACH: A REVIEW ON ECONOMIC VERSES IN TAFSIR AL-AZHAR BY HAMKA (1908-1981)
}

\author{
A. H. Usman ${ }^{1 *}$, M. Ibrahim², M. N. A. Kadir² \\ 1Faculty of Islamic Civilisation Studies, Kolej Universiti Islam Antarabangsa Selangor (KUIS), 43000, \\ Malaysia \\ ${ }^{2}$ Faculty of Islamic Studies, National University of Malaysia (UKM), Malaysia \\ *aburhamdi@kuis.edu.my
}

\begin{abstract}
Tafsir al-Azhar is one of the popular masterpieces of Indonesian exegete, Hamka. This paper discusses one of Hamka's great exegetical works. The focus is on his discussion of economic affairs in particular, capitalism, usury and corruption, in the selected text in particular those related to. A qualitative method is adopted in this paper in which selected documents are analysed. This paper found that Hamka has unique approaches in this respect that are closely related to the socio-cultural aspects of Indonesia. Again, like other exegetes, Hamka applies al-ijtima' $i$ in his work. This method seeks to understand the Qur'an by studying its expressions carefully and elaborating their meanings beautifully and interesting style of language in the context of existing cultural system.
\end{abstract}

Keywords: Economic, Hamka, Society, Capitalism, Interest, Corruption

\section{INTRODUCTION}

Tafsir (exegesis) of the Qur'an is very important for Muslims. All matters concerning the Islamic way of life are connected to it as proper understanding of Islam guided by Allah is vital to live a Muslim way of life. Without tafsir, it would not be possible to have a right understanding of Qur'an (Von Denver, 1983). Man's purpose is to worship Allah, i.e. to seek His pleasure by living the way of life Allah has prescribed. A Muslim can do so within the framework of the guidance that Allah has revealed concerning this, but he/she can do so only with a proper understanding of its meanings and implications (Kadir et al., 2014).

The traditional Muslim view on the origins of tafsir place it with the Qur'an itself, Prophet Muhammad, and various Companions (Rippin, 1987). Other researchers, however, basing their conclusions on literary evidence, have debated the existence and nature of the earliest, namely first/ seventh century, tafsir (Mackay, 1991). But it is sufficient here, merely to establish that there exists substantial evidence to support the fact that written works of tafsir had emerged at the latest by the second/eighth century (Watt, 1970). The second/eighth and third/ninth centuries witnessed a proliferation of a variety of types and styles of exegetical works (Sattar, 1978), including those which were based only on the author's own opinion (tafsir bi al-ra'y) and those which cited earlier traditional authorities for their explanations of the Qur'an (tafsfir bi al-ma thur) (Jullandri, 1968). It was the latter method which embraced and regulated earlier opinion and eventually came to define a true work of classical tafsir which saw its beginnings in the early fourth/tenth century with the compendium tafsir, Jami al-Bayan fi Tafsir al-Qur'an, of al-Tabari (d. 310/923), after which, few methodological innovations were introduced. Yet, just as the fourth/tenth century marked the beginning of classical Muslim exegesis, it also marked the end of tafsir formative period. As mentioned earlier, a number of different exegetical styles emerged during this period which John Wansbrough has divided into five logical and manageable types: narrative, legal, textual, rhetorical, and allegorical. But these divisions should be seen as general demarcations of exegetical works, rather than their authors, since the literary activities of the latter can often be found, not only within a number of tafsir styles, but in a variety of disciplines (Mackay, 1991).

In the Archipelago, in the context of the Malay-Indonesian world, where Islam has been firmly established since the beginning of the 14th century (Riddell, 2014), early history has proven the 
writing of the tafsir in Malaysia is not as incessant as its development in Indonesia. The study of Islam in the territories that now comprise Indonesia must in the first place be the urban settlements and portcity states which where the first centres for the establishment of Islamic learning and the further diffusion of the religion (Johns, 2005). The Malay community in the glorious era of Islamic studies has always been in a state of seeking religious sciences. At that time the Malay Islamic community only took the basis of religious knowledge, especially in relation to daily life and human affairs. Not surprisingly, the development of tafsir is somewhat later and dispersed from the aspect of its study in Malay Land if compared to other sciences such as jurisprudence, Theology, or Tasawuf.

Such material, however, seems to have generally fallen out of favor in more 'systematic' works of tafsir produced in Malay-Indonesian world since the mid-seventeenth century. And from that time on we find the field being almost exclusively held by one work, the Tarjuman Mustafid by 'Abd al-Rauf al-Singkili (1615-1693) (Feener, 1998). Followed by Tafsir Nur al-Ihsan by Muhammad Said bin Umar (1854-1932), Tafsir Harian al-Quran al-Karim by Haji Abdullah Abbas Nasution (1912-1987), Tafsir al-Quran al-Hakim by Mustafa Abdul Rahman (d. 1968), etc., including Tafsir al-Azhar by Haji Abdul Karim Amrullah, better known by the nickname Hamka (1908-1981), as one of the major reference source and well-known among the Malay community.

Hamka is a prominent figure in the Malay World especially in Indonesia. He is not only known as a scholar and even a literary, historian and Islamic poet. The creation of Tafsir al-Azhar raises his name in the eyes of Muslims. What is amazing that throughout his lifetime he left a lot of work that have been recorded or not. His writings cover a wide range of subjects that affect the politics, history, economics, cultural, moral, and Islamic sciences fields.

\section{HAMKA: A GREAT INDONESIAN EXEGETE}

Hamka is an Indonesian religious scholar and the most prolific of modern Indonesian Islamic writers. He was born in the small village of Sungai Batang in the Minangkabau region of West Sumatra on February 17, 1908. His mother came from the adat aristocracy, and his father, Dr. Abdulkarim Amrullah, a member of long-established 'ulama' family, was a pioneer in the modernist reform movement. Although his father was the leading teacher of a traditional religious school, the Famous Sumatra Thawalib, Hamka was enrolled in the Diniyyah school, the first religious school to use the modern system of education, established by Zainuddin Lebay al-Junusyah (Osman \& Muhedat, 2009). Hamka was not successful there and transferred in 1922 to Parabek (Bukit Tinggi), a school run by another modernist Syeikh Ibrahim Musa. Instead of studying the kitabs, he preferred Minangkabau traditional literature. It was only after he suffered a serious case of smallpox in 1923 that he began in earnest the career of a talented autodidact. Hamka was self-taught, a brilliant striver with a unique voice and range as a writer (Rush, 2016).

In 1924, Hamka went to Java to visit his older sister, whose husband A.R Sutan Mansyur was the chairman of the local branch of The Muhammadiyah. The visit gave him a chance to attend public courses presented by important Muslim leaders. At the end of 1925 he entered the world of journalism by sending articles to the daily Hindia Baru, edited by Haji Agus Salim, an Islamic political leader. On his return to Padang Panjang, Hamka established the first Muhammadiyah journal, Chatibul Ummah. He soon travelled to Medan and to Mecca in 1927. The short but intense exposure to the Arab world not only immensely improved his linguistic ability, but also introduced him to the treasures of Arabic literature.

On his return to padang Panjang, he began his career as a writer. His first book, a Minangkabau novel titled Si Sabariah (A Girl Named Sabariah) was published in 1925. He regularly sent articles to local journals and published booklets on Minangkabau adat and Islamic history. His activities in Muhammadiyah organization brought him to Makassar (1932-1934), where he published two journals, novels, and book on Islamic history. In 1936, he received an offer to become the editor in chief of a new Islamic journal in Medan, Pedoman Masyarakat. Under his editorship the journal became one of the successful in the history of Islamic journalism in Indonesia. The sojourn in Medan (1936-1945) was the most productive time of Hamka's life, during this period he published most of his novels, notably $D i$ bawah Lindungan Ka'bah (1936) and Tenggelamnya Kapal Van Der Wijck (1937), as well as his noted 
books on Islamic ethics and mysticism, including Tasauf Modern (1939), Lembaga Budi (1939) and Falsafah Hidup (1940).

At the same time, Hamka was a leading figure in the revolutionary struggle for national independence in West Sumatra from 1945 to 1049. In 1950, he moved to Jakarta. Appointed as a high official of the Department of Religious Affairs, Hamka spent most his time to teaching, writing, editing and publishing the Journal Panji Masyarakat. In 1950 he published a widely acclaimed biography of his father, Ayahku, which also gives a historical account of Islamic movements in Sumatra. In addition to his four-volume memoir Kenang-kenangan Hidup and the first volume of the projected four-volume Sedjarah Umat Islam. In 1955, Hamka was elected a member of the Constituent Assembly, representing the Islamic Modernist political party, The Masjumi. His political career ended with the dissolution of the Assembly by President Sukarno. In 1960, he was elected as 'great imam' of al-Azhar Mosque. Falsely accused of involvement in the attempted murder of President, he was detained in 1964. He spent twenty months in the hospital, where he completed the drafts of his thirty-volume Tafsir Al-Azhar.

After the fall of Sukarno, Hamka was released and resumed his position as the great Imam of al-Azhar Mosque with its prestigious elementary and secondary school. As the most sought-after mubaligh (public speaker) and the popular broadcast personality with books published in Malaysia, Singapore and Indonesia, he was undoubtedly the most famous religious scholar in the Malay-speaking World. In 1975 he accepted the post of chairman of the new government-sponsored Indonesian Council of Ulama and was reelected in 1980, but he resigned owing to a political conflict with the minister of religion. His position, however, had popular support and congratulatory letters flooded his house. A few months after the last volume of Tafsir Al-Azhar was published, Hamka died on July 21, 1982, leaving ten children.

Hamka wrote more than one hundred books, including fiction, politics, Minangkabau adat, history and biography, Islamic doctrine, ethics, mysticism and tafsir. About twenty of these have enjoyed several reprintings and are still in print. Several collections of his writings have also been published posthumously. He received honorary degrees from Al-Azhar University in Cairo (1958) and The National University of Malaysia in Kuala Lumpur (1974) (Yusof, 2005). The daily Berita Buana named him Man of the Year in 1980. He was also the 'spiritual father' of most newly converted Chinese.

A keen student of history, Hamka not only made the long-forgotten past alive, but also never failed to find the moral messages that history held for the present. His literary works show his concern for the little people and the human sufferings in his transitional society. His writings in Minangkabau reflect the attitude of a modernist alim toward his matrilineal society. He offered an influential interpretation of the Indonesian national ideology, the Pancasila, by making its first principle the recognition of the oneness of God. Since his major concern was the maintenance of faith and creed in changing times, it is understandable that in his tafsir he often deviates from the traditional Asyhariate School of theology, which is still the foundation of Islamic orthodoxy in Indonesia (Abdullah, 2009).

\section{TAFSIR AL-AZHAR: THE MAGNUM OPUS OF HAMKA}

In Qur'anic exegesis regional differences can, to a large extent, be explained by differences in the structure and curricula of academic theology within the Islamic World. The genre of tafsir tends to be a domain of academic theologians and a relatively conservative field; boldly innovative approaches to the interpretation of the Qur'an are more frequently found in other exegetical genres (Pink, 2010a.). Mystical inclinations coloured much of Hamka's approach to Islamic teaching, but he was a reformist Sufi approach that affirmed the legal requirements of the faith. He strongly criticized any syncretistic practice that mixed customary law with Islam. It was during his time in prison that Hamka wrote most of his Qur'anic commentary, entitled Tafsir Al-Azhar. The materials came initially from a series of lectures delivered in Jakarta at the Al-Azhar Mosque. This commentary has been published in several editions in Jakarta, Kuala Lumpur and Singapore. It has a lengthy introduction, in which Hamka defines his target audience as, first, young Indonesian Muslim needing a sense of direction in their theological formation and, second, those active in $d a^{\prime} w a$ (mission). His commentary shows his reformist inclinations: concerned with a weakening of Islam in the face of contemporary secular intellectual rationalism, Hamka set himself the goal of equipping his readers to cope with modern intellectual challenges by reinforcing basic Islamic principles that were under threat. Hamka identifies his approach 
to exegesis as one based on the use of $r a^{\prime} y$ (opinion). He encourages his readers to develop their own ability to engage critically with the primary texts of Islam. Hamka identifies his sources as the Tafsir AlManar by the reformist Rashid Rida, the commentary by the more Islamist Sayid Qutb and diverse classical commentaries in Arabic. He also expresses admiration for the Malay language commentaries by Abd Al-Rauf, Mahmud Yunus and Hasbi Ash-Shiddieqy (Riddell, 2006).

Tafsir al-Azhar shows the breadth of Hamka which almost covers all informational in Islamic religious disciplines. This work comes from a series of lectures delivered by Hamka at the al-Azhar Mosque located in Kebayoran Baru Jakarta since 1959 (Yusof, 1990). The name of Mosque, al-Azhar, was given by Syeikh Mahmoud Syaltout, Rector of the al-Azhar University during his visit to Indonesia in December 1960 in the hope that it would be al-Azhar in Jakarta. The naming of Tafsir al-Azhar is in conjunction with the birthplace of this Grand Mosque (Hamka, 1966). Tafsir al-Azhar was written during Hamka in custody of the old Order government. In 1962-1966, Hamka experienced the fate of many convinced and important religious leaders: Emprisonment by order of the Soekarno regime. This period was 'a time of grace' for him, because now he had the time to write a full commentary of the Qur'an, which was published in thirty volumes during the next ten years (Steenbrink, 1995). Hamka's copious commentary draws on a number of authorities with a heavy emphasis on modern Egyptian exegeses, especially that of Sayyid Qutb. However the commentary is not simply a rehashing of Egyptian modernism under the rubric of Qur'anic exegesis, but rather incorporates select elements of Egyptian modernism and other aspects of Muslim tradition with a considerable bit of originalitycontaining even a number or revealing personal anecdotes. This work continues to enjoy considerable popularity not only in Indonesia, but other parts of Southeast Asia as well, including Malaysia and Singapore (Feener, 1998).

This work is produced to meet the needs of Indonesian Muslims who are keen to understand the contents of the Qur'an, but do not master the Arabic language. In addition, he also helps Muslims missionaries who have the ability to speak Arabic, but do not yet have the breadth of knowledge in delivering $d a$ 'wah. This work has become one of the primary

resources for Muslim scholars, especially among Muhammadiyah scholars, in studying tafsir of the Qur'an (Murodi, 2007).

\section{METHOD OF IJTIMA'I IN QUR'ANIC INTERPRETATION}

As most exegetes' aim is to stress the timeless relevance of the Qur'an, few of the commentaries make direct reference to contemporary events. Still, many of them are, in a very modern way, more concerned with providing religious guidance than with explaining the Qur'an's meaning (Pink, 2010b.). The word of method comes from the Greek methodos which describes the way. In Arabic it was translated as tariqat or manhaj which means an orderly way of achieving a purpose or a systematic work ethic to facilitate the implementation of activities to achieve what is being determined. In general, the method is one of the most important ways to achieve the goals that have been set (Baidan, 1998; 2002).

Ijtima' $i$ is derived from Arabic words that are always mentioned and used in daily life. It means society application context. It depicts a life filled with people and tribes that enable them to live together in peace and harmony. Therefore, Islam sets out the basics in the community and social life and is highly demanded to be practiced for every Muslim that is mentioned in the Qur'an, sura al-An'am verses 151-152. From both verses, the importance of Islamic policy to be practiced in today's society which is worship to Allah, good deeds to parents, do not commit adultery, kill, persecute orphans, etc. These are the rules and Islamic policies that have been outlined and it was very necessary to be followed so that people are not misled by the path of Islam (Hamzah, 1964).

In explaining the meaning of the term method of ijtima' $i$ is also included in the debate of the ijmali (global) method. According to the development of the Qur'anic interpretation, so far in the field of interpretation was done through four methods, ie: ijmali (global), tahlili (analysis), muqarin (comparison) and mawdu'i (thematic). The birth of these methods caused by the wider development of society. In the days of the Prophet and his companions, they were generally Arabic experts and knew the background of the verses as well as the reasons of revelation and directly experienced the situation when the Qur'anic verses were revealed. Therefore, they can understand the Qur'anic verses deeper, 
true, precise and clear. In later times, Muslims flourished with the existence of various races comprising non-Arabs who embraced Islam, especially after the spread of Islam to areas beyond Arab land. This situation has also affected the development of Islamic thought by bringing a variety of non-Islamic civilizations and cultures into Islamic intellectual treasures (Baidan, 1998; 2002).

Consequently, unknowingly, the lives of Muslims began to be affected by the change. To confront the situation, an interpretation expert began to apply it by providing the form of interpretations of the Qur'anic verses in line with the progress of the times and the demands of the lives of the ummah which are widespread and changed according to the current situation. Thus, Muslims will understand better with the explanations given to the various interpretations in respect of the Qur'anic verses. Then such an interpretation method is followed by the scholars in two forms of interpretation, namely al-ma thur and $a l-r a$ ' $y i$ with various patterns produced such as jurisprudence (Fiqh), tasawuf, philosophy (falsafi), sciences (ilmi), social community (adabi ijtima'i), and others (Baidan, 1998; 2002).

In general, method of al-Ijtima' $i$ is a pattern of interpretation which explains the instructions of the verses of the Qur'an that are directly related to society, as well as attempts to tackle the diseases of society or their problems based on the instructions of the inner verses in simple explanations to understand but beautifully heard (Shihab, 2007). It is arguable that method of al-Ijtima' $i$ is a community-oriented interpretation of literature, which emphasizes the explanation of the Qur'anic verses in terms of its sentence accuracy, then composing the contents of the verses in a beautiful editorial with a purpose of prominence the main decline of the verses, then concludes the notion of the verses with the laws of nature that apply in society and the development of the world. Method of alIjtima ' $i$ seeks to understand the Qur'an by introducing Quranic expressions carefully, also elaborating the meanings of the Qur'an with a beautiful and interesting language style, then in the next step the exegete tries to connect the Qur'anic verses is being studied with the social reality and the existing cultural system (al-Dhahabi, 1962). Like other exegetes, Hamka also applies method of al-ijtima ' $i$ in his work Tafsir al-Azhar.

\section{THE IJTIMA'I METHOD RELATES TO ISLAMIC ECONOMICS IN TAFSIR AL-AZHAR}

All over the world are competing to improve their economy. This is due to the economy could be considered the key or the pulse of life. When the economy is strong, the country will prosper and becoming stronger in all areas, including industrial, technological and military. By doing so, the strong economic country able to dominate the other countries.

Muslim countries also do not want to miss. They also strive to compete and raced to catch up with other countries. However, the economic system that they adopted similar with the Western capitalist system. The effects of this system unsuitable to be applied in Muslim countries, due to it is more concerned about repressive and material gain alone. The more advanced human beings in the economy, the more corrupt the nature of humanity, missing unity and love, there is no balance and justice in society. This is because the rich are getting richer, the poor are getting worse. This is what brought by Hamka in his Tafsir Al-Azhar he was trying to clarify the question to overcome the problems that existed. Among the issues covered by Hamka relating to Islamic economics, such as capitalism in business, the prohibition of riba and corruption.

\section{Capitalism in Business}

The economies of developing societies today are, in the main, dependent on the advanced capitalist countries and form a part of the international capitalist system. The political independence of these former colonies and semi-colonies did not lead to economic independence because the colonial social and economic structures remained more or less intact. Hence, the larger economic decisions of what to produce, how to produce and for whom to produce in these economies, remained in the hands of indigenous ruling elites and foreign colonialists. As the modern world has come to be divided into two polarised economic systems of capitalism and socialism, with antagonistic models and world-views, the social and economic problems of Third World countries have been aggravated for lack of a coherent plan, purpose, direction and identity. They vacillate between the two poles. Economic chaos, social anarchy and intellectual confusion are the natural outcome of their general aimlessness (Haque, 1992). 
Economics is a necessity for human life, therefore it must be dealt with in a proper, fair, equitable and compassionate way. However, at this time, economic activity has been abused and corrupted by human reasoning, especially with communist and capitalist ideology, which is aimed at gaining profits and exaggeration no matter what, even in the wrong way. Thus, there arose pressure, oppression and injustice, then there was a crisis, conflict, distress, corruption and even disunity. This is what Hamka is trying to explain about the capitalist system found in today's economy. There are so many verses in the Quran that explain the greedy attitude of human beings which misled them from the real path as in sura al-Tawbah verse 34. According to the description of this verse, Hamka (1984) explains that amongst the people themselves take the opportunity to use their rank and position to take other property in the wrong way in various ways irrespective of threatening, and deceptive. Because of fear being punished, then their wills be followed. Some people tend to do driven on the basis of self-interest. Therefore, because of the greed on the property causes them to collect it for their own wealth and for the sake of maintaining the crony's relationship.

Therefore, as described in the above verse, whoever collects property in the wrong way, even though he is a leader or even an Islamic scholar or anyone else, if they collect property but are not spent in the way of Allah, then the painful torment will receive from God. In the next verse, sura al-Tawbah verse 35 , this verse reminds strongly against those who practice capitalism in business because of the terrible reward and punishment to be received by them in the Hereafter. Gold, silver, or any property they collect will be roasted and baked until melted due to extremely hot then thrown into their whole body as a result of this bad attitude (Hamka, 1984).

Actually, this verse as well as to remind, it also guide people to think that no wrong to collect the property, gold or silver or any precious as long as in lawful ways and immediately donated to the path of Allah to strengthen religion and also for the benefit of society. According to the narration of Ibn cAbbas, when this verse sent down many of the Muslims were shocked at the reminder of the verse which is relatively hard. Due to there was the question of the prohibition of collecting property, whereas they have children that can be passed on when they died later. When Umar bin al-Khattab heard this complaint from the companions he came to the Prophet then answered by saying:

\section{"Verily, Allah has enjoined the zakat to make it good on your property and also He made the heirs division compulsory to the property would you leave behind."}

According to the Prophet's answer, Hamka said it lost all doubts and confusion of the Muslims over the years. Apparently we may collect and saving property as long as it is sourced from halal. With all the rules of zakat, the collected property could be cleaned even if those who died did not cause problems due to all the remaining property can be passed on to the rightful (Hamka, 1984).

Based on the above verse that Islam does not prohibit in collecting of property as long as it is lawful, and even excessive it can be donated. But the problem now is the human greed that led to their deviation from the path that has been prescribed by Him.

\section{Prohibition of Practicing Riba}

Muslims are prohibited from engaging in interest (riba) related economic activities. Muslims worldwide is pioneering efforts in shariah-complaint finance. This includes prohibitions on: investments in businesses whose practices are in conflict with Islamic teachings such as those that engage in gambling or pornography, or the sale or consumption of alcohol and pork; investments offering fixed interestbased return; investments in indebted companies paying interest on servicing their debt; and speculation in derivative transactions on the stock exchange (Vahed \& Vawda, 2008).

In the realm of economic activity, the Quran appears to favour commerce, to condemn fraudulent practices, and to require abstention from trade during festivals. The clearest and strongest prohibition is on riba and there is an obligation to pay zakat - alms for the needy, distributed through a welfare fund controlled by the state (Jomo, 1992). In a modern life now requires a lot of demands that are needed, especially economic purpose. To meet those demands, there are those who use improper ways to gain excessive profits, for example, in a competitive business world by lending to individuals who are so 
desperate to multiply their rates. This what is riba means, a thing that God hates most. Many verses are interpreted by Hamka regarding the dangers of riba as described in sura al-Baqarah verse 275.

Riba has been traced at the time of pagan. It is the nature of the behavior extremely despicable and inconsistent with the lives of believers. If the time already exists, now due to they had converted to Islam necessarily quit to continue in such lowly condition. If you have stopped, the previous sins will be erased and forgiven by Allah. Therefore, from now Muslims are advised to stop completely from such a lifestyle. But if there are still back with usury lifestyle, then it would be like to return to worship idols. Therefore, they will stay together in the Hellfire. (Hamka, 1966). In sura al-Baqarah verse 276, Allah says which means:

\section{"Allah destroys interest and gives increase for charities. And Allah does not like every sinning disbeliever."}

Hamka explained that the purpose of this verse in order to eliminate the practicing of riba totally. This stems from the evils of life as long as given the interest to themselves prosper and let other people's lives impoverished. Hereby it could be declared that the blessing of usury is nothing, because it is vanity wealth and could lead to resentment and disaster with no end. If the disease is contagious and spreads it lead to the emergence of attitudes thickened hate and vengeance on each other. Therefore, God is a more encouraging attitude of charity because it can strengthen the relationship of love between the giver and the recipient (Hamka, 1966).

As result is that the community will also be transformed into a mutually-helping, cooperative and mutual community. This is the life favored by Allah as explained in sura al-Baqarah verse 276 earlier. In the explanation of the other verse, Allah has brought the same reminder that in sura al-Baqarah verse 277. In this verse, Hamka (1966) describes that God has explained that in a good society what is highly recommended is charity practice rather than riba practice. People who believe and do good deeds often will not practice riba. This is because even if they are rich or poor but in a single faith and a united with mutual intentions to one another.

If we read this verse thoroughly, it ends with a guarantee from God that one will not be overwhelmed with fear, grief and sorrow if practicing the right way of life without spending on riba. So it can be understood how much the influence of this verse in eradicating riba.

\section{Corruption}

Islam is a rules-based religion. Rules are spelled out and Muslims are required to be ruled compliant. Islam's teachings on human and economic development are expounded in the Quran and were operationalized by the traditions of the Prophet Mohammad. The Quran provides the framework and specifies rules (institutions) that are, to a degree, abstract; the traditions of the Prophet articulate the operational form of these rules and provide the foundational structure of a society centred on the Oneness of God. During the 13 years the Prophet spent in Medina, he detailed and practiced all the following rules regarding: governance, accountability, and transparency; property ownership and protection; the formation and the structure of the market; the role of the state vis-a-vis the market; behavior by market participants; distribution and redistribution; education, technological progress, and society's infrastructure; and, finally, government income and expenditure (Askari, 2013).

Corruption or misappropriation takes place everywhere. Not just in the days of the Holy Prophet, but in the present time, which are widely seen in economic, legislative and political institutions. The various parties are trying to address this problem, but are still happening and continue to occur. In the Prophetic era, they try to handle it, because of the existence of a group of greedy and irresponsible people then this thing goes on. In sura Ali 'Imran verse 161 there is a description of this issue.

In this verse there is a description of a yaghul which means a person who takes something and hides it with other items. It is also the case with people who get the booty (ghanimah) and hide it so that it does not belong to the division of war property. It same with the situation by stealing. According to the rules of war, the booty must be collected first after the war. Then will be divided equally and fairly by the 
head of the army in its discretion and the balance will be given to Baitul Maal. According to the Prophet (pbuh) he will do the same by collecting all the booty first and then dividing it fairly into 5 parts, i.e. for those who walk and ride, for Allah and His Messengers as mentioned in the sura al-Anfal verse 41, for the nearest family, orphans, the poor and the sick people during the course of the war. This verse is obviously to repel the misunderstanding to the Prophet (pbuh) by the man who made the accusation that Prophet (pbuh) took all. According to a narration by Abu Dawud, Al-Tirmidhi, Ibn Jarir from Ibn Abbas this verse descends because during the Battle of Badr after the booty was collected it was found to have lost a "khalifah" that was a red wool (scarlet) head cover in winter. Then there are those who confess and suspect that maybe the Prophet (pbuh) himself, who took it for his use. However the person who said this does not mean to accuse or mislead even to feel that the Prophet (pbuh) takes it is his right. But this narration is weak (daif) for some commentators because Ibn Abbas's narration relates to the Uhud war only (Hamka, 1984).

Through this verse Hamka explains that we can take lessons from the Prophet's attitude and morality despite being the leader of the armed forces and even the head of the country, despite holding the wealth of the nation's property has never been treacherous and devious as has ever been in the present administration. The teaching of this verse as discussed by Hamka (1984) means that on the Day of Judgment will open the secret of evil committed by anyone. This is because he will come by himself with the stuff he was cheating on, whatever he cannot hide from the evil he has ever done.

\section{CONCLUSION}

The Qur'an is an excellent value of Allah's words. There is no match and no other creation can match it. To understand the contents in more depth there are many efforts made by the experts in the field of writing, especially in the science of interpretation. As Hamka did in his very famous masterpiece, Tafsir Al-Azhar, which is the main ingredient of this paper.

Tafsir al-Azhar has its own aesthetic value because of his work is still used today. Many of the matters discussed in Tafsir al-Azhar by solving each question are related to the problems that occur in society, such as economic, and legal as well as political systems that are happening in our daily life. Every problem that Hamka arises is explained in each chapter according to the problem and he submits the course of the solution based on the verses of the Qur'an, and this can be clearly if we interpret it comprehensively or look at the ijtima' $i$ method found in his exegetical work. For example, raising issues such as usury, corruption in modern society today is alarming. This is because of the impairment of noble values in the lives of individuals and communities. Self-esteem and jealousy of the enjoyment and success of others led to a crime. The society is losing its strength and is exposed to various types of criminal threats due to the deprivation of purity and moral values. Strong leadership factors also play an important role in shaping the moral ethics of every member of the community, especially leaders based on leadership qualities through example and emphasizing piety and faith in Allah.

\section{REFERENCES}

Abdullah, T. (2009). Hamka. In The Oxford Encyclopedia of the Islamic World. Oxford University Press, pp. 373-375.

al-Dhahabi, M. H. (1962). Al-Tafsir wa al-Mufassirun. Dar al-Kitab al-Arabi.

Askari, H. (2013). Oil-Islam, ownership, and institutions. In Collaborative Colonialism. Palgrave Macmillan, pp. 115-124.

Baidan, N. (1998). Metodologi penafsiran Al-Quran. Glagah UH.

Baidan, N. (2002). Metode penafsiran Al-Quran: Kajian kritis terhadap ayat-ayat yang beredaksi mirip. Pustaka Pelajar.

Feener, R. M. (1998). Notes towards the history of Qur'anic exegesis in Southeast Asia. Studia Islamika, 5(3), 47-76.

Hamka. (1966). Kenang-Kenangan Hidup. Kuala Lumpur: Penerbitan Pustaka Antara.

Hamka. (1984). Tafsir Al-Azhar. Pustaka Panjimas.

Hamzah, A. B. (1964). Sejarah kebudayaan Islam. Pustaka Aman Press.

Haque, Z. (1992). Islamic perspectives and class interests. In Islamic Economic Alternatives, Palgrave Macmillan, pp. 105-116. 
Jomo, K. S. (1992). Islam and capitalist development: A critique of Rodinson and Weber. In Islamic Economic Alternatives. Palgrave Macmillan, pp. 125-138.

Jullandri, R. A. (1968). Qur'anic exegesis and classical tafsír. Islamic Quarterly, 12(1), 71-119.

Kadir, M. N. A., Usman, A. H., Ibrahim, M., \& Ali, M. A. M. (2014). An analysis on Shihab's methodology: How do pronouns applied? Asian Social Science, 10(17), 185-193.

Mackay, F. W. (1991). Ibn Qutayba's understanding of Quranic brevity. Master thesis, McGill University.

Murodi, M. (2007). Al-Amr Bi Al-Ma'ruf Wa Al-Nahy 'an Al-Munkar: Dirasah Fi Ara'i Al-'Alim Hamka Fi Tafsir Al-Azhar. Studia Islamika, 14(2).

Osman, R. A., \& Muhedat, K. A. M. (2009). A bird's eye view on Muslim scholarship in Southeast Asia. International Journal of the Humanities, 7(3).

Pink, J. (2010a.). Tradition, authority and innovation in contemporary Sunni tafsir: Towards a typology of Qur'an commentaries from the Arab World, Indonesia and Turkey. Journal of Qur'anic Studies, 12(1-2), 56-82.

Pink, J. (2010b.). Tradition and ideology in contemporary Sunnite Qur'anic exegesis: Qur'aānic commentaries from the Arab World, Turkey And Indonesia and their interpretation of Q 5: 51. Die Welt des Islams, 50(1), 3-59.

Riddle, P. G. (2006). Hamka. In The Qur'an: An Encyclopedia. Routledge, pp. 241.

Riddell, P. G. (2014). Translating the Qur'àn into Indonesian languages. Al-Bayan: Journal of Qur'an and Hadith Studies, 12(1), 1-27.

Rippin, A. (1987). Tafsir. In The Encyclopedia of Religion. Macmillan Publishing Company, pp. 237.

Rush, J. R. (2016). Hamka's great story: A master writer's vision of Islam for modern Indonesia. University of Wisconsin Press.

Sattar, M. A. (1978). Wujuh Al-Qur'an: A branch of tafsir literature. Islamic studies, 17(2), 137-152.

Steenbrink, K. A. (1995). Qur'an interpretations of Hamzah Fansuri and Hamka. Studia Islamica, 2, 73-96.

Shihab, M. Q. (2007). Membumikan al-Qur'an. PT. Mizan Pustaka.

Vahed, G., \& Vawda, S. (2008). The viability of Islamic banking and finance in a capitalist economy: A South African case study. Journal of Muslim Minority Affairs, 28(3), 453-472.

Von Denver, A. (1983). Ulum Al-Quran: An introduction to the sciences of the Qur'an. Islamic Fondation.

Watt, M. (1970). Bell's introduction to the Quran. Edinburgh University Press.

Yusof, W. S. W. (2005). Religious harmony and inter-faith dialogue in the writings of HAMKA. Intellectual Discourse, 13(2), 113-134.

Yusuf, M. Y. (1990). Corak pemikiran kalam Tafsir al-Azhar: Sebuah telaah tentang pemikiran Hamka dalam teologi Islam. Pustaka Panjimas. 